\title{
Analysis of Environmental Bonds in Mexican Pacific Major Ship Grounding
}

\section{Marina Mondragon, Anamaría Escofet}

Department of Marine Ecology, Centro de Investigación Científica y de Educación Superior de Ensenada, Ensenada, México. Email: aescofet@cicese.mx

Received June $6^{\text {th }}, 2013$; revised July $11^{\text {th }}, 2013$; accepted August $13^{\text {th }}, 2013$

Copyright (c) 2013 Marina Mondragon, Anamaría Escofet. This is an open access article distributed under the Creative Commons Attribution License, which permits unrestricted use, distribution, and reproduction in any medium, provided the original work is properly cited.

\begin{abstract}
Environmental bonds are a means to accounting for future environmental costs, yet examples of application in real-life scenarios are scarce, and estimation of fairness of the bonds is still poorly explored. We examined a recent Mexican Pacific maritime accident in which the aid of extra environmental assessments addressing long-lasting effects was needed, and contributed to the decision-making process of environmental authorities by means of an arrangement based on the legal figure of the environmental bond. The basis to estimate the bond was the cost of activities needed to fulfill compensatory measures, specifically, the cost of research programs that would set a baseline for monitoring long-lasting damage to the bottom. In order to proceed with analysis of environmental bonds, we employed cluster analysis for comparing mean depth, grain size, and composition and abundance of benthic fauna at the three sites set for monitoring long-lasting effects, under the assumption that no differences would mean bond overestimation whereas differences would mean fairness. The results show that the three sites were different enough to justify the spatial setting of three separate sampling campaigns, and that the bond was reasonably not overestimated. The approach appears suitable to address in a semi-analytical way current inquiries regarding fairness of the environmental bonds and so may contribute to the state of the art.
\end{abstract}

Keywords: Soft Bottom Impacts; Environmental Bonds; Cluster Analysis; Todos Santos Bay

\section{Introduction}

Grounding of the $11 \mathrm{~m}$ in draft cargo ship APL Panama in December 2005 was a unique event on the coasts of Todos Santos Bay (Baja California, Mexico). Grounding was spectacular for the ship stayed still on soft bottoms in waters less than $8 \mathrm{~m}$ in depth and the entire cargo remained intact on board, Figure 1(b). Rescue maneuvers for refloating the boat lasted almost three months.

The evaluation of the whole event required the aid of extra environmental assessments that focused particularly on sea-bottom long-lasting effects, and contributed to the decision-making process of environmental authorities by means of an arrangement based on the legal figure of the environmental bond.

The basis to estimate the bond was the cost of activities needed to fulfill compensatory measures, specifically, the cost of research programs that would set a baseline for monitoring long-lasting damage to the bottom.

Three different impact sources were acknowledged for grounding and rescue maneuvers. Accordingly, three sites were set to track the long-lasting effects on the sea bottom, and to perform the first monitoring sampling campaign [1].

The use of environmental bonds to address long-lasting effects was a novelty when the environmental evaluation of the APL Panamá ship grounding occurred. Further reviews [2] showed that the procedure had been previously utilized in the environmental evaluation of coral reef accidents occurred in 1998, 2001 and 2005, and in a 2008 accident afterwards. Indeed, the state of the art revealed that a gap exists regarding procedures to estimate fairness of a given bond [3].

In order to address that specific gap we performed cluster analysis comparing the three sites previously set for monitoring long-lasting effects and to estimate the bond. The assumption was that no differences would mean bond overestimation whereas differences would mean fairness. We propose that the bond was reasonably not overestimated, since the three sites were different enough to justify separate sampling campaigns. 
(a)

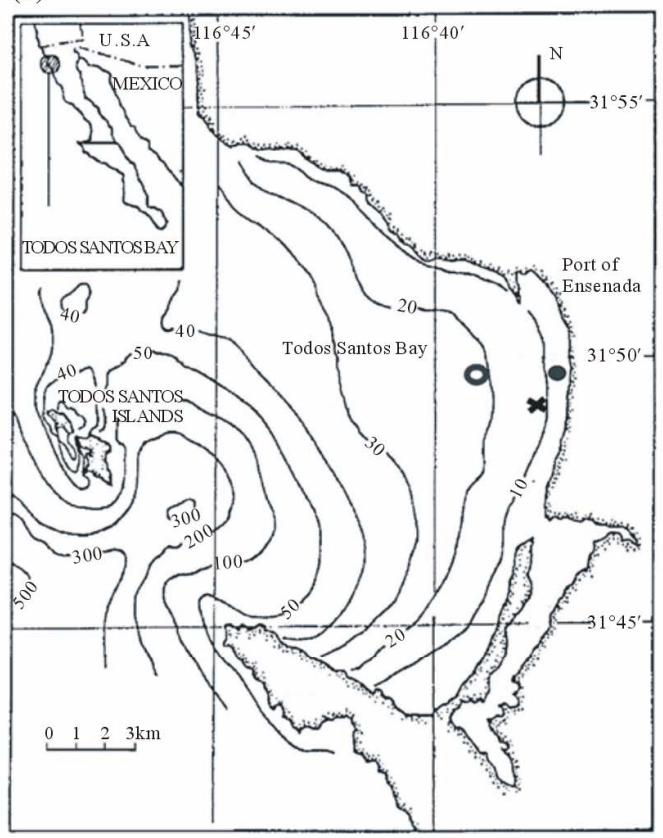

(b)

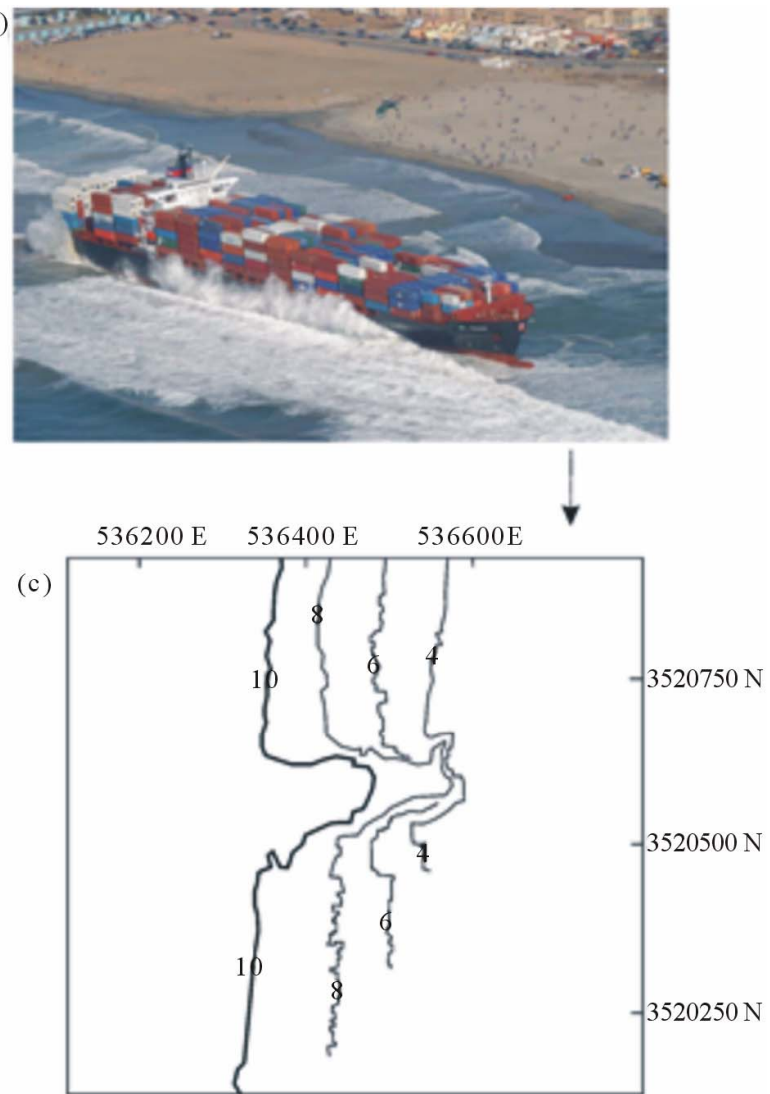

Figure 1. The study area: (a) bathymetry of Todos Santos bay (geographic units) and the position of grounding and channel dredging site (full circle) deposit of dredged sediments site (cross) and mooring site (empty circle); (b) aerial view of the APL Panamá at the grounding site; (c) bathymetry of the dredging site (UTM units) right after dredging, denoting in bold the 10 $m$ isobath. Source: $a$ and $c$ are redrawn from [1,2]; $b$ is from [1]

\section{Conceptual Framework}

The concept of environmental bonds is tightly linked to that of future environmental costs, which are a central point in the decision-making process of environmental authorities [4]. In practice, the issue demands the combined effort of lawyers, economists, policy makers, and insurance experts [5,6]. Environmental bonds are adequate to address the aim of compensatory measures, a category acknowledged by most environmental regulations in which the existence of long-lasting, probably irreversible effects is accepted, and some kind of indemnification is considered fair [1].

Environmental bonds that would provide an incentive to conduct research on the future effects of specific activities has been proposed to reveal potential future costs of activities having no historical precedents [4]. The spirit of that proposal is adequately reflected in the Mexican Environmental Law (Ley General del Equilibrio Ecológico y la Protección al Ambiente, LGEEPA, by its Spanish acronym) and correspondent Environmental Impact Assessment (EIA) regulations [1,2].

In the decision-making process of environmental authorities the practical consequences of setting a proper bond are non-trivial, for the offender's compliance depends on the accuracy of the calculation. Overestimation could lead to claims by the offender, and delays in the administrative process may occur, whereas underestimation may overlook environmental injuries. In fact, the dilemma is always at issue, and a gap still exists regarding procedures to estimate fairness of a given bond [3].

\section{Methods}

\subsection{Background}

Impacts on sea bottom were the more impressive effects of ship grounding that deserved compensatory measures. Dragging the ship out of very shallow waters required dredging a channel at the grounding site. The channel was $350 \mathrm{~m} \times 50 \mathrm{~m} \times 10 \mathrm{~m}$, and brought forth the need to deposit 70,000 $\mathrm{m}^{3}$ of dredged sediments. The ship was then towed to a temporary mooring site at the center of Todos Santos Bay. Accordingly, the addressed sources of impact were (a) channel dredging; (b) disposal of dredged sediments and (c) potential impacts during mooring (e.g. spills), Figure 1. 
The research program for setting a baseline for further monitoring long-lasting damages included a) the design of three georeferenced sampling grids, one for each site, and b) a first sampling campaign in each site, in October and November 2006. The channel dredging site sampling grid was $400 \times 600 \mathrm{~m}$ and comprised 12 stations; the disposal of dredged sediments site sampling grid was 700 $\times 300 \mathrm{~m}$ and comprised 15 stations; the mooring site sampling grid was $400 \times 400 \mathrm{~m}$ and comprised 9 stations,

\section{Figure 2.}

The October-November sampling campaign included only depth and sediments for analysis of fauna, but missed sediments for grain size analysis. In order to proceed with further monitoring, a special research program on a yearly basis was created, in which all three issues are being addressed ${ }^{1}$.

\subsection{The Research Question}

The research question was: considering that three sites were set to track the long-lasting effects on the sea bottom, are the sites different enough so as to merit the spatial setting of three separate sampling campaigns?

The rationale underlying this question was that no differences would mean bond overestimation whereas differences would mean fairness.

\subsection{The Procedure}

To compare the sites we performed cluster analysis on the basis of available data on depth, grain size, and benthic organisms. Cluster analysis is an accepted multivariate statistical technique for analyzing and interpreting environmental quality data sets at a regional level. Clustering proceeds by calculating similarity among entities. A visual summary of the results of the clustering process is usually depicted in a dendrogram [7].

Data taken during the first sampling campaign (2006) were employed for depth and benthic organisms. To solve the fact that grain size data were not available for the 2006 campaign, we took our own data from the October-November 2008 campaign under the assumption that the 2006 and 2008 conditions would be the same. This extrapolation was supported by preliminary data of the monitoring program now in progress, showing no changes in sediments in the 2008 to 2009 interval [2].

To run the cluster analysis according to depth, data of the sampling grid at each site were arranged to obtain single values of mean depth, standard deviation and depth range, Table 1.

For grain size of sediments, data of the sampling grid at each site were arranged to obtain mean values of the different size fractions, Table 2.

For benthic fauna, species-abundance data was added to the sampling grid to obtain total abundance of each species at each site, Table 3.

Analyses were performed with the MVSP program ver. 3.01 for Windows (Multi-Variate Statistical Package).

Gower's General Index of Similarity was employed
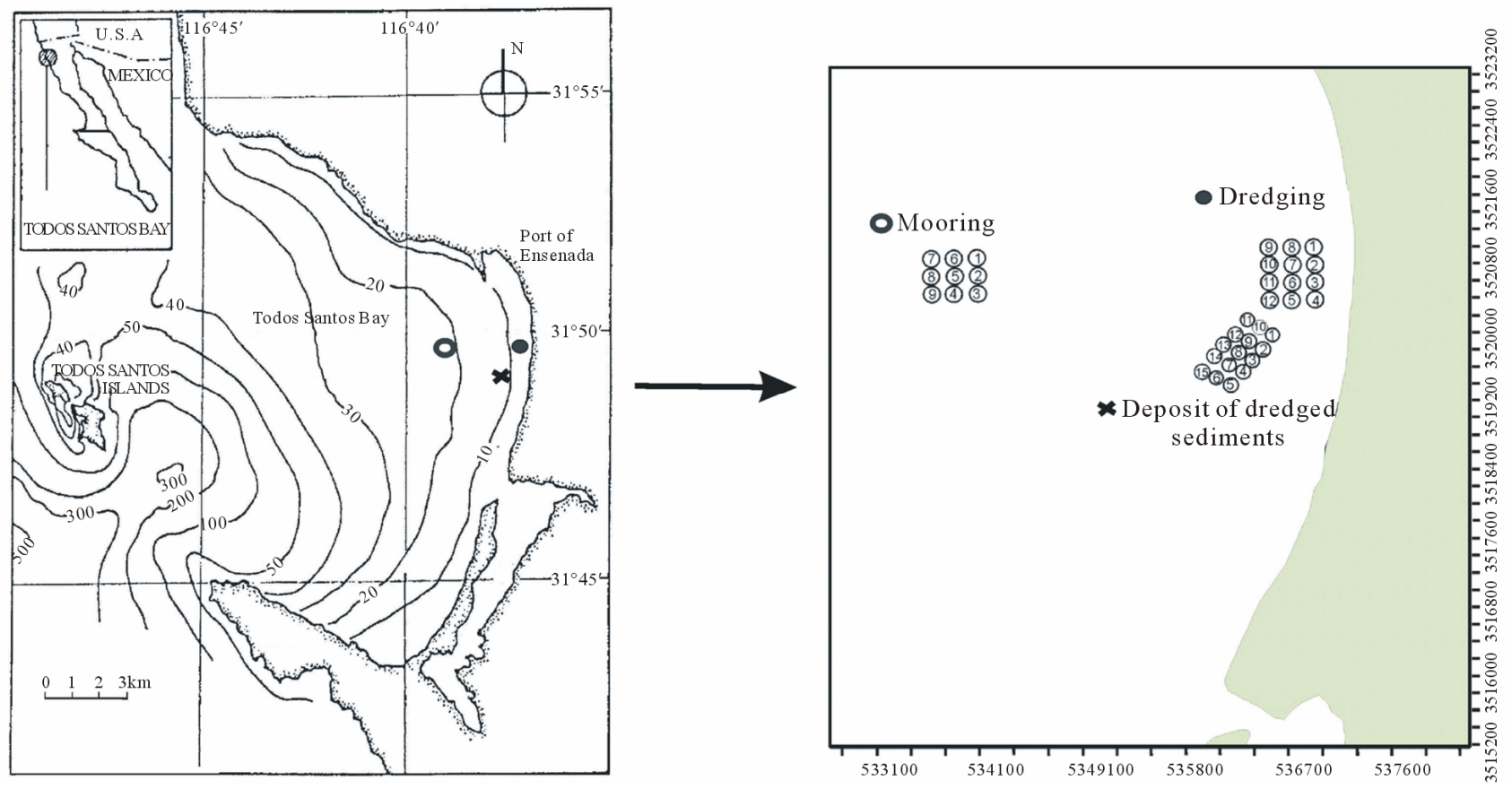

Figure 2. Design of the three georeferenced sampling grid. Source: [2].

\footnotetext{
${ }^{1}$ Escofet, internal research project at CICESE, 2008 to date.
} 
Table 1. Depth data of the sampling grid of each site, showing mean depth, standard deviation and depth range. Source: [2].

\begin{tabular}{|c|c|c|}
\hline Sites & Stations & Depth (m) \\
\hline \multirow{12}{*}{ 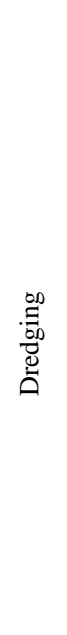 } & 1 & 6 \\
\hline & 2 & 8 \\
\hline & 3 & 8 \\
\hline & 4 & 6 \\
\hline & 5 & 11 \\
\hline & 6 & 11 \\
\hline & 7 & 12 \\
\hline & 8 & 11 \\
\hline & 9 & 13 \\
\hline & 10 & 14 \\
\hline & 11 & 15 \\
\hline & 12 & 15 \\
\hline
\end{tabular}

Mean $=10.83 ;$ SD $=3.21 ;$ Range $=6-15$

\begin{tabular}{|c|c|c|}
\hline & 1 & 11 \\
\hline & 2 & 12 \\
\hline & 3 & 12 \\
\hline & 4 & 11 \\
\hline & 5 & 13 \\
\hline 离 & 6 & 13 \\
\hline & 7 & 14 \\
\hline 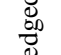 & 8 & 13 \\
\hline 吾 & 9 & 13 \\
\hline$=$ & 10 & 12 \\
\hline .़े & 11 & 13 \\
\hline & 12 & 13 \\
\hline & 13 & 13 \\
\hline & 14 & 13 \\
\hline & 15 & 13 \\
\hline
\end{tabular}

Mean $=12.60 ; \mathrm{SD}=0.83 ;$ Range $=11-13$

\begin{tabular}{|c|c|c|}
\hline & 1 & 23 \\
\hline & 2 & 23 \\
\hline & 3 & 22 \\
\hline & 4 & 22 \\
\hline$\stackrel{0}{ }$. & 5 & 23 \\
\hline & 6 & 22 \\
\hline & 7 & 23 \\
\hline & 8 & 23 \\
\hline & 9 & 22 \\
\hline
\end{tabular}

Mean $=22.56 ; \mathrm{SD}=0.53 ;$ Range $=22-23$
Table 2. Grain size of sediments in the sampling grid of each site, and mean values of the different size fractions. Source: [2].

\begin{tabular}{|c|c|c|c|c|}
\hline Sites & Station & $\%$ Fine sands & \%Very fine sands & \%Silt \\
\hline \multirow{14}{*}{$\begin{array}{l}\stackrel{0}{\mathscr{G}} \\
.000 \\
\ddot{\mathscr{D}}\end{array}$} & 1 & 4.3 & 87.6 & 8.1 \\
\hline & 2 & 5.4 & 86.6 & 7.9 \\
\hline & 3 & 25.9 & 72.6 & 1.5 \\
\hline & 4 & 18.9 & 78.5 & 2.6 \\
\hline & 5 & 13.7 & 79.6 & 6.7 \\
\hline & 6 & 5.5 & 84.8 & 9.7 \\
\hline & 7 & 7.6 & 84.2 & 8.2 \\
\hline & 8 & 4.5 & 85.3 & 10.2 \\
\hline & 9 & 1.9 & 71.3 & 26.8 \\
\hline & 10 & 6.9 & 71.0 & 22.1 \\
\hline & 11 & 4.7 & 73.0 & 22.2 \\
\hline & 12 & 3.5 & 67.4 & 29.1 \\
\hline & Mean & 8.6 & 78.5 & 12.9 \\
\hline & 1 & 1.1 & 80.1 & 18.8 \\
\hline \multirow{14}{*}{ 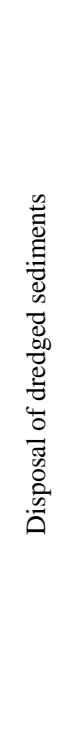 } & 2 & 1.3 & 75.8 & 22.9 \\
\hline & 3 & 1.5 & 71.5 & 27.0 \\
\hline & 4 & 1.6 & 76.1 & 22.3 \\
\hline & 5 & 0.9 & 81.2 & 17.9 \\
\hline & 6 & 0.5 & 76.8 & 22.7 \\
\hline & 7 & 0.7 & 77.5 & 21.8 \\
\hline & 8 & 0.7 & 79.3 & 20.0 \\
\hline & 9 & 1.6 & 82.2 & 16.1 \\
\hline & 10 & 1.2 & 82.0 & 16.8 \\
\hline & 11 & 1.0 & 78.2 & 20.7 \\
\hline & 12 & 2.5 & 79.6 & 17.9 \\
\hline & 13 & 1.9 & 76.8 & 21.2 \\
\hline & 14 & 0.5 & 75.8 & 23.7 \\
\hline & 15 & 0.5 & 71.7 & 27.8 \\
\hline \multirow{11}{*}{ 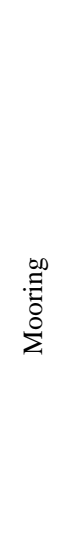 } & Mean & 1.2 & 77.6 & 21.2 \\
\hline & 1 & 1.5 & 53.4 & 44.5 \\
\hline & 2 & 2.0 & 41.6 & 55.7 \\
\hline & 3 & 1.0 & 28.5 & 70.5 \\
\hline & 4 & 1.1 & 19.6 & 76.7 \\
\hline & 5 & 1.2 & 36.1 & 62.7 \\
\hline & 6 & 0.7 & 43.6 & 55.7 \\
\hline & 7 & 1.1 & 41.7 & 56.9 \\
\hline & 8 & 2.4 & 31.7 & 65.9 \\
\hline & 9 & 1.0 & 21.7 & 77.0 \\
\hline & Mean & 1.3 & 35.3 & 62.9 \\
\hline
\end{tabular}


Table 3. Species composition and abundance of benthic fauna at dredging (Dre) deposit (Dis) and mooring (Mo) sites. Species are listed by decreasing total abundance. Source: [2].

\begin{tabular}{|c|c|c|c|}
\hline Species & Dre & Dis & Mo \\
\hline 1 Apoprionospio pygmaea & 1046 & 127 & 18 \\
\hline 2 Mediomastus ambiseta & 125 & 689 & 0 \\
\hline 3 Chaetozone corona & 0 & 0 & 613 \\
\hline 4 Nereis procera & 136 & 120 & 284 \\
\hline 5 Aphelochaeta monilaris & 0 & 47 & 479 \\
\hline 6 Pista cristata & 130 & 344 & 2 \\
\hline 7 Chaetozone setosa & 21 & 289 & 141 \\
\hline 8 Ampharete labrops & 371 & 64 & 3 \\
\hline 9 Arabella iricolor & 53 & 341 & 0 \\
\hline 10 Scoloplos armiger & 21 & 234 & 0 \\
\hline 11 Nemertea & 141 & 111 & 0 \\
\hline 12 Aphelochaeta sp & 49 & 2 & 190 \\
\hline 13 Nephtys cornuta & 22 & 91 & 82 \\
\hline 14 Nematoda & 33 & 26 & 87 \\
\hline 15 Paraprionospio pinnata & 22 & 53 & 45 \\
\hline 16 Goniada maculata & 56 & 46 & 12 \\
\hline 17 Photis californica & 81 & 21 & 0 \\
\hline 18 Pycnogonida & 99 & 0 & 0 \\
\hline 19 Polydora sp & 91 & 7 & 0 \\
\hline 20 Glycera americana & 47 & 23 & 15 \\
\hline 21 Polycirrus californicus & 1 & 76 & 0 \\
\hline 22 Euclymene sp & 0 & 0 & 67 \\
\hline 23 Siphodentalium quadrifisatum & 0 & 16 & 39 \\
\hline 24 Onuphis iridescens & 6 & 1 & 41 \\
\hline 25 Tellina bodegensis & 8 & 30 & 8 \\
\hline 26 Myscidacea & 27 & 13 & 5 \\
\hline 27 Cyclaspis sp & 7 & 36 & 0 \\
\hline 28 Uromunna ubiquita & 34 & 9 & 0 \\
\hline 29 Amphilochus picadurus & 42 & 0 & 0 \\
\hline 30 Calanus sp & 13 & 25 & 3 \\
\hline 31 Lytechinus arenicola & 41 & 0 & 0 \\
\hline 32 Gammanospis thompsoni & 32 & 6 & 1 \\
\hline 33 Callianassa californiensis & 2 & 34 & 0 \\
\hline 34 Phyllodoce longipes & 7 & 20 & 5 \\
\hline 35 Cumacea & 21 & 8 & 0 \\
\hline 36 Petrochirus californiensis & 28 & 0 & 0 \\
\hline 37 Ophioderma panamense & 10 & 15 & 2 \\
\hline 38 Chione californiensis & 17 & 9 & 0 \\
\hline 39 Platelminta & 8 & 8 & 9 \\
\hline 40 Polydora $s p$ & 11 & 4 & 10 \\
\hline 41 Malmgreniella macginitiei & 13 & 12 & 0 \\
\hline 42 Campylaspis sp & 19 & 2 & 0 \\
\hline 43 Paradiopatra parva & 9 & 9 & 0 \\
\hline 44 Tubulanus sp & 0 & 0 & 17 \\
\hline 45 Sabella sp & 0 & 1 & 15 \\
\hline 46 Turbonilla sp & 0 & 1 & 14 \\
\hline 47 Amphiporus sp & 0 & 0 & 14 \\
\hline 48 Rictaxis puntocaelatus & 1 & 4 & 9 \\
\hline 49 Ampelisca sp & 9 & 4 & 1 \\
\hline 50 Sipunculida & 0 & 0 & 13 \\
\hline 51 Lytechinus anamensus & 0 & 13 & 0 \\
\hline 52 Arctonoe pulchra & 13 & 0 & 0 \\
\hline 53 Scyphozoa & 8 & 0 & 4 \\
\hline 54 Nassarius fossciatus & 0 & 4 & 7 \\
\hline 55 Clylichnella digensis & 0 & 11 & 0 \\
\hline 56 Amphicteis scaphobranchiata & 3 & 4 & 4 \\
\hline 57 Eualus lineatus & 10 & 1 & 0 \\
\hline 58 Euphysora bigelowi & 11 & 0 & 0 \\
\hline
\end{tabular}

\section{Continued}

59 Nephtys californiensis

60 Prionospio lighti

61 Ampelisca agassizi

62 Photis brevipes

63 Eteone californica

64 Chaetozone sp

65 Ampelisca brevismulata

66 Parapleustes pugettensis

67 Lumbrineris japonica

68 Acteocina eximia

69 Leptopecten latiauritus

70 Listriella diffusa

71 Tiron sp

72 Phoronida

73 Pinnixa spp

74 Chaetognata

75 Cylincha sp

76 Solen rostriformis

77 Mopaldia scyphozoa

78 Spiochaetopterus costarum

79 Cirrophorus furcatus

80 Harmothoe fragilis

81 Kurtzina beta

82 Lirobittium larum

83 Prionospio dubia

84 Crepidula glottidiarum

85 Crangon nigromaculata

86 Caprella equilibra

87 Cylincha panamense

88 Lottia sp

89 Musculista eximia

90 Paguristes sp

91 Clymenura gracilis

92 Scoletoma tetrura

93 Scoloplos acmeceps

94 Odostomia $\mathrm{sp}$

95 Tiron biocellata

96 Pista wui

97 Pista percyi

98 Acteocina $s p$

99 Exogone sp

100 Monoculodes hartmanae

101 Asabellides lineata

102 Brachiopoda

103 Clione limacina

104 Colonia plumaria

105 Haliophasma sp

106 Mesocrangon munitella

107 Musculista senhousia

108 Nephtys caecoides

109 Pandora sp

110 Tritella tenuissima

111 Balcis sp

112 Nuculana sp

113 Haliophasma germinatum

114 Melphisana bola

115 Ophiodermella inermis

116 Owenia collaris

Total individuals

Total species

\begin{tabular}{|c|c|c|}
\hline 11 & 0 & 0 \\
\hline 0 & 0 & 10 \\
\hline 1 & 0 & 9 \\
\hline 8 & 0 & 2 \\
\hline 6 & 3 & 0 \\
\hline 1 & 7 & 0 \\
\hline 2 & 0 & 6 \\
\hline 7 & 0 & 0 \\
\hline 0 & 0 & 6 \\
\hline 0 & 5 & 1 \\
\hline 3 & 0 & 3 \\
\hline 4 & 0 & 2 \\
\hline 6 & 0 & 0 \\
\hline 0 & 5 & 0 \\
\hline 3 & 2 & 0 \\
\hline 5 & 0 & 0 \\
\hline 0 & 0 & 4 \\
\hline 3 & 0 & 1 \\
\hline 4 & 0 & 0 \\
\hline 4 & 0 & 0 \\
\hline 0 & 0 & 3 \\
\hline 0 & 3 & 0 \\
\hline 0 & 3 & 0 \\
\hline 0 & 3 & 0 \\
\hline 0 & 3 & 0 \\
\hline 1 & 1 & 1 \\
\hline 2 & 1 & 0 \\
\hline 3 & 0 & 0 \\
\hline 3 & 0 & 0 \\
\hline 3 & 0 & 0 \\
\hline 3 & 0 & 0 \\
\hline 3 & 0 & 0 \\
\hline 0 & 0 & 2 \\
\hline 0 & 0 & 2 \\
\hline 0 & 0 & 2 \\
\hline 0 & 1 & 1 \\
\hline 0 & 1 & 1 \\
\hline 0 & 2 & 0 \\
\hline 1 & 0 & 1 \\
\hline 2 & 0 & 0 \\
\hline 2 & 0 & 0 \\
\hline 2 & 0 & 0 \\
\hline 0 & 0 & 1 \\
\hline 0 & 0 & 1 \\
\hline 0 & 0 & 1 \\
\hline 0 & 0 & 1 \\
\hline 0 & 0 & 1 \\
\hline 0 & 0 & 1 \\
\hline 0 & 0 & 1 \\
\hline 0 & 0 & 1 \\
\hline 0 & 0 & 1 \\
\hline 0 & 0 & 1 \\
\hline 0 & 1 & 0 \\
\hline 0 & 1 & 0 \\
\hline 1 & 0 & 0 \\
\hline 1 & 0 & 0 \\
\hline 1 & 0 & 0 \\
\hline 1 & 0 & 0 \\
\hline 3052 & 3053 & 2326 \\
\hline 77 & 62 & 62 \\
\hline
\end{tabular}


for depth and grain size analysis, and Pearson's Coefficient of Similarity for benthic fauna analysis.

Linking strategy was UPGMA (Unweighted Pair Group Metric Average).

The $50 \%$ was taken as benchmark to ascribe degrees of similarity.

\section{Results}

Dendrograms showed strong differences (only $4 \%$ and $20 \%$ similarity) or weak similarity (55\% and 60\%) among sites. Dredging was the more dissimilar site according to depth, whereas mooring was the more dissimilar according to grain size and fauna, Figure 3.

According to depth parameters, the dredging site was considerably different (only 20\% similarity) and the other two were $60 \%$ similar. These results reflect the profound alterations that dredging imposed on the bottom profile, and also suggest that depth standard deviation and depth range are preferable to mean depth to describe the impact.

According to grain size, the mooring site was very different from the rest (only 20\% similarity) and the other two were $55 \%$ similar. This is consistent with predominance of silt and very fine sands at the mooring site, and the prevalence of very fine sands at dredging and deposit sites. The results reflect direct impact that occurred at dredging and deposit sites, and null impact at the mooring site.

According to benthic organisms, the mooring site was

Depth

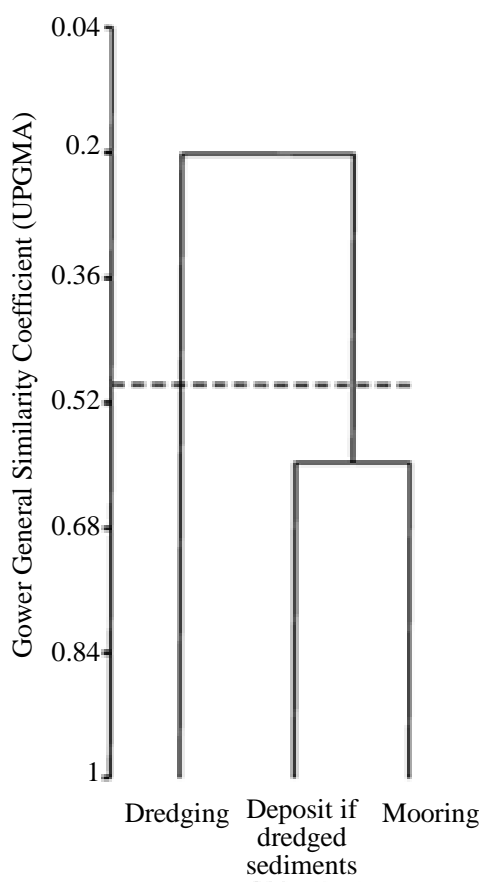

Grain size

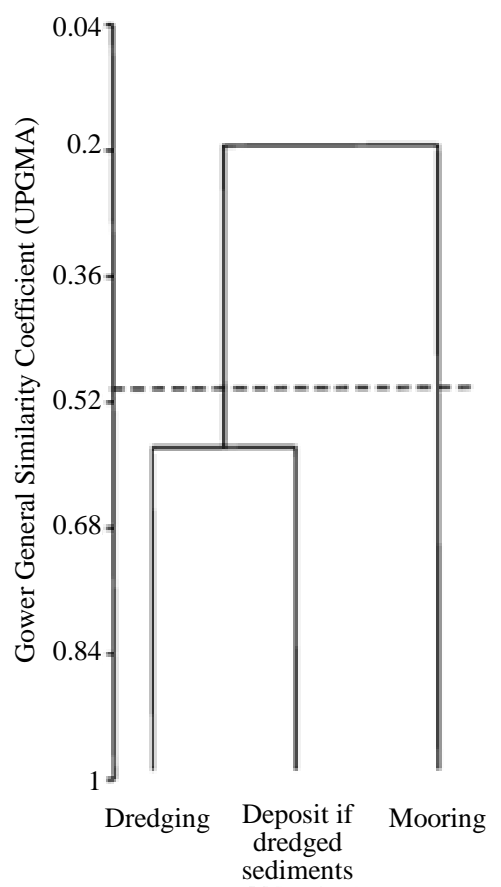

the more dissimilar (only $4 \%$ similarity) and the other two had less than $50 \%$ similarity. These results appear in accordance with exclusive presence or overwhelming abundance of species such as Aphelochaeta monilaris and Chaetozone setosa at the mooring site, as well as meager or null abundance of species such as Apoprionospio pygmaea and Mediomastus ambiseta which were dominant at dredging and deposit sites. The results may reflect the direct impacts that occurred at dredging and deposit sites, and null impacts at the mooring site.

\section{Discussion and Conclusions}

In the original study [1] the basis to estimate the bond was the cost of activities needed to fulfill compensatory measures, specifically, the cost of research programs that would set a baseline for monitoring long-lasting damage to the bottom. In that sense, the structure of the approach fulfilled the aim of environmental bonds that would provide an incentive to conduct research on the future effects of specific activities [4].

Our study is coherent with these approaches since novel research was conducted to further explore current inquiries. In general, our results endorse the hypothesis that sites were different enough to justify the spatial setting of three separate sampling campaigns, and that the bond was reasonably not overestimated. To our knowledge, no attempts to address the issue in an objective mode have been made in Mexico before.

The way we linked levels of similarity among the sites

Figure 3. Dendograms of spatial clustering of sampling sites. The dashed line indicates the $50 \%$ similarity level. Source: [2]. 
with some kind of decision-making diagnosis has few precedents. Betters and Rubingh [8] related different levels of similarity with the identification of homogeneous land parcels as a way to define specific management units. Ortiz-Lozano [9] associated different levels of similarity with homogeneous coral reef units as a way to assign management policies.

Our analysis rested on impact sources and ecological routes identified in the original environmental evaluation. In the light of our results, it appears that a sound spatial representation of impacts and reasonable ecological routes are essential to proceed with further analysis on the environmental bond issue.

A georeferenced grid of the impacted area, like the one set in the original study, appears also important for spatial monitoring. In that sense, only one out of four Mexican cases in which environmental bonds have been applied would be apt to proceed in the same way we did. Specifically, only the environmental evaluation of grounding of the Cembay vessel on Caribbean coral reefs would serve, for it included spatial and temporal settings [2].

In our study area, further advances in the environmental bond issue would cover temporal monitoring. In the event of the Cembay accident, cited above, a ten-year period was set after the advice of coral reefs dynamics experts. In our case, a recovery of the bottom profile at the dredging site was visible 14 months after removal of the ship [1] and preliminary results of the monitoring program now in progress show that the process continued for at least four years, suggesting that a minimum fiveyear period would be suitable to address future environmental costs in soft bottoms.

Our approach appears suitable to address existing inquiries regarding fairness of environmental bonds. It may contribute to the state of the art and in the decisionmaking process of environmental authorities as well. In any case, our effort would confirm that the legal figure of the environmental bond deserves being part of the coastal professional's toolbox [1].

\section{Acknowledgements}

This study is part of the first author's M.Sc. Thesis at Universidad Autónoma de Baja California under the guidance of the second author. We are grateful to the members of the Thesis Committee, C. Leyva and C. Peynador, for their support. Careful reading and comments by G. Torres-Moye and L. D. Ortiz-Lozano allowed substantial improvement of the manuscript. English editing by L. Orensanz is deeply appreciated.

\section{REFERENCES}

[1] C. Peynador and A. Escofet, "An ad-hoc Procedure for the Environmental Assessment of Ship Grounding at Todos Santos Bay (Baja California, México): Lessons and Perspectives,” In: G. T. Halley and Y. T. Fridian, Eds., Environmental Impact Assessments, Nova Science Publishers, Inc., New York, 2009, pp. 193-224.

[2] M. Mondragón, "La Figura de Fianzas Ambientales Como Instrumento de Gestión: Lecciones Aprendidas a Partir del Varamiento del APL Panamá en la Bahía de Todos Santos (Baja California, México),” Tesis de Maestría, Facultad de Ciencias, Universidad Autónoma de Baja California, Mexicali, 2013.

[3] M. García and A. Martínez "Seguros y Fianzas Ambientales,” In: M. García-Vázquez, A. Martínez-Cruz and C. Rodríguez-Castelán, Eds., Compiladores, Teoría y Práctica de los Seguros y Fianzas Ambientales, INE-SEMARNAT, México, 2003, pp. 15-35.

[4] Ch. Perrings, "Environmental Bonds and Environmental Research in Innovative Activities," Ecological Economics, Vol. 1, No. 1, 1989, pp. 95-110. doi:10.1016/0921-8009(89)90026-8

[5] Swiss Re, “The Insurability of Ecological Damage,” 2003. http://www.alhermij.com/pws/research\%20publications/ri sk\%20and\%20expertise/technical\%20publishing/the\%20i nsurability\%20of\%20ecological\%20damage.html

[6] M. Faure, "Environmental Damage Insurance in Theory and Practice," 2001.

http://www.cserge.ucl.ac.uk/Faure.pdf

[7] E. Salah, A. Turki and E. Al-Othman, "Assessment of Water Quality of Euphrates River Using Cluster Analysis,” Journal of Environmental Protection, Vol. 3, No. 12, 2012, pp. 1629-1633. doi:10.4236/jep.2012.312180

[8] D. R. Betters and J. L. Rubingh, "Suitability Analysis and Wild Life Classification: An Approach,” Journal of Environmental Management, Vol. 7, No. 1, 1978, pp. 59-72.

[9] D. L. Ortiz-Lozano, “Análisis Crítico de las Zonas de Regulación y Planeación en el Parque Nacional Sistema Arrecifal Veracruzano,” Tesis de Doctorado, Facultad de Ciencias Marinas, Universidad Autónoma de Baja California, Mexicali, 2006. 